\title{
Size at Sexual Maturity in the Female Red King Crab (Paralithodes camtschaticus) in a Newly Settled Population in the Barents Sea, Norway
}

\author{
Ann Merete Hjelset \\ Institute of Marine Research, \\ Tromsø P.O. Box 6404, 9294 Tromsø, Norway \\ E-mail: ann.merete.hjelset@imr.no \\ and \\ Department of Aquatic BioScience, \\ Norwegian College of Fishery Science, \\ University of Tromsø, N-9037 Tromsø \\ Jan H. Sundet \\ Institute of Marine Research, \\ Tromsø P.O. Box 6404, 9294 Tromsø, Norway \\ Einar M. Nilssen \\ Department of Aquatic BioScience, \\ Norwegian College of Fishery Science, \\ University of Tromsø, N-9037 Tromsø
}

Hjelset, A. M., J. H. Sundet, and E. M. Nilssen. 2009. Size at sexual maturity in the female red king crab (Paralithodes camtschaticus) in a newly settled population in the Barents Sea, Norway. J. Northw. Atl. Fish. Sci., 41: 173-182. doi:10.2960/J.v41.m633

\begin{abstract}
The aim of this study was to estimate and discuss the variation in the $50 \%$ ovigerous length $\left(O L_{50}\right)$ of female red king crab (Paralithodes camtschaticus) sampled from three Norwegian fjords in the Barents Sea. Egg status from 19872 females were collected and analysed from 1994-2007. Females were defined as sexually mature based on the observed presence of eggs or past presence of eggs (egg remnants). Differences in the $O L_{50}$ value according to the sample year and fjord were illustrated, but were to a large degree caused by large numbers of young females representing strong year-classes that passed through the size distribution over time. In Varangerfjorden, the mean $O L_{50}$ was $108.9 \pm 0.2 \mathrm{~mm} \mathrm{CL}$ for a 14 year sampling period. The mean $O L_{50}$ estimates were $108.7 \pm 0.3 \mathrm{~mm}$ and 111.8 $\pm 0.5 \mathrm{~mm} C L$ for a nine and six year sampling period in Tanafjorden and Laksefjorden, respectively. Russian scientists successfully introduced the red king crab into the Barents Sea during 1960-1969 with the aim of establishing a fishery. The red king crab stock has since grown and extended its distribution. Norway started fishing red king crab in 1994, and the harvest rate has increased gradually since the onset of the commercial fishing. Female red king crab appears to mature at a larger size in the Barents Sea than those found in its native areas.
\end{abstract}

Keywords: Barents Sea, female red king crab, size at maturity.

\section{Introduction}

Size at sexual maturity is a key life history parameter in fishery management of exploited populations, and it is recommended that data on this parameter be collected routinely particularly during the early stages of fishery exploitation (Watters and Hobday, 1998). It is imperative that some individuals in the population be protected and have the opportunity to reproduce before they reach legal catch size and enter the fishery (Somerton, 1981; 
Donaldson and Donaldson, 1992). Hence, size at maturity is important in the context of stock reproductive strategy and output. Large size at maturation is beneficial for a high reproductive potential in general (Stearns, 1992). It has been suggested that high fishing pressure may reduce the size at maturity (Stearns, 1976; Pollock, 1995). Today it is well documented in the literature that fish populations respond to exploitation by a decrease in the size at maturity due to increased mortality (Trippel 1995; Jørgensen et al., 2007). The determination of size at sexual maturity is fundamental for achieving management goals, be it extirpation of an unwanted species or the creation of a sustainable fishery.

Size at maturity in crabs can be determined using morphometric, gonadal and behavioural data. Different methods provide different estimates, as physiological gonadal maturity will occur prior to morphometric maturity which is followed by behavioural maturity. The latter is the stage at which individuals start reproducing (Watters and Hobday, 1998).

Red king crab (Paralithodes camtschaticus) fisheries have been economically important in the North Pacific Ocean and the Bering Sea for decades. Therefore Russian scientists intentionally introduced the red king crab to the Barents Sea during the 1960s (Orlov and Karpevich, 1965; Orlov and Ivanov, 1978), and in 1977 the first red king crab was caught in Norwegian waters (Orlov and Ivanov, 1978). The red king crab has since established a self-sustaining population (Kuzmin et al., 1996) and increased its numbers in the Barents Sea. The current population in Norwegian waters is estimated at 4.3 million individuals (Institute of Marine Research, Norway, unpublished data).

In the native area of red king crab it is known that adults undertake a spring migration to shallow water areas to mate and breed (Marukawa, 1933; Powell and Nickerson, 1965). The same migratory pattern was observed in the Barents Sea by Kuzmin et al. (1996), who observed grasping pairs of king crab in April. Mature male crabs undergo irregular moults and with increasing carapace size the probability of an annual molt declines (Hayes and Montgomery, 1963; McCaughran and Powell, 1977), as was also observed for male red king crab in the Barents Sea (Nilssen and Sundet, 2006). Female red king crab moult before spawning (McCaughran and Powell, 1977; Nilssen and Sundet, 2006). New studies carried out by Stevens and Swiney (2007a) showed that the reproductive cycle of red king crab can span from 326 days (multiparous) to 365 days (primiparous), and the moulting, mating and release of larvae can start as early as December and continue until April, and is a function of female size. The female red king crab has an annual reproductive cycle in the Barents Sea and in its native areas.

Since the red king crab is an introduced species the management rules governing the fishery were nonexistent. Therefore a research fishery for red king crab occurred from 1994 to 2001, and it was exempt from fishery regulations. Commencing in 2002 it has been a commercial fishery and since then the quota has increased according to crab abundance and distribution. Presently, two management regimes are implemented in Norwegian waters: one is to sustain a commercial fishery within a limited geographical area; the other to limit further spreading of crab into new areas. The commercial stock is managed according to the ' 3 -S' regime (sex, size and season), and only males with a carapace length (CL) larger than $137 \mathrm{~mm}$ can be landed during the fishery, after the Alaskan model (Otto, 1986; Kruse, 1993). A new component of the management regime of 2008 was that females larger than $137 \mathrm{~mm} \mathrm{CL}$ will be included in the legal catch.

To our knowledge, few long-term studies exist that have collected maturity data for female red king crab. Therefore it is of great scientific interest to investigate the variation in size at sexual maturity for females in the introduced and expanding population of red king crab along the Norwegian coast, with the aim of generating a starting point for future monitoring of this parameter. The purpose of this study was to investigate whether female red king crab in Norwegian waters, due to the favourable conditions met by the introduced crab and the initial lack of a fishery and low exploitation rate, mature at sizes different from crabs found in native areas. Due to the expansion of the population westward along the Norwegian coast, the crab has been present in three main fjords (Varangerfjorden, Tanafjorden and Laksefjorden) for about 30, 20, and 10 years, respectively. We suggest that these three areas represent different stages in crab population development and density. Thus, we examined if this difference in population density is related to female size at maturity.

\section{Materials and Methods}

Red king crabs were caught in Varangerfjorden, Tanafjorden and Laksefjorden (Fig. 1). In this part of northern Norway (the county of Finnmark) three large fjords dominate the landscape and form large inlets. These fjords also consist of smaller side arms and polls, and reach depths of 300-400 m. Varangerfjorden has a 


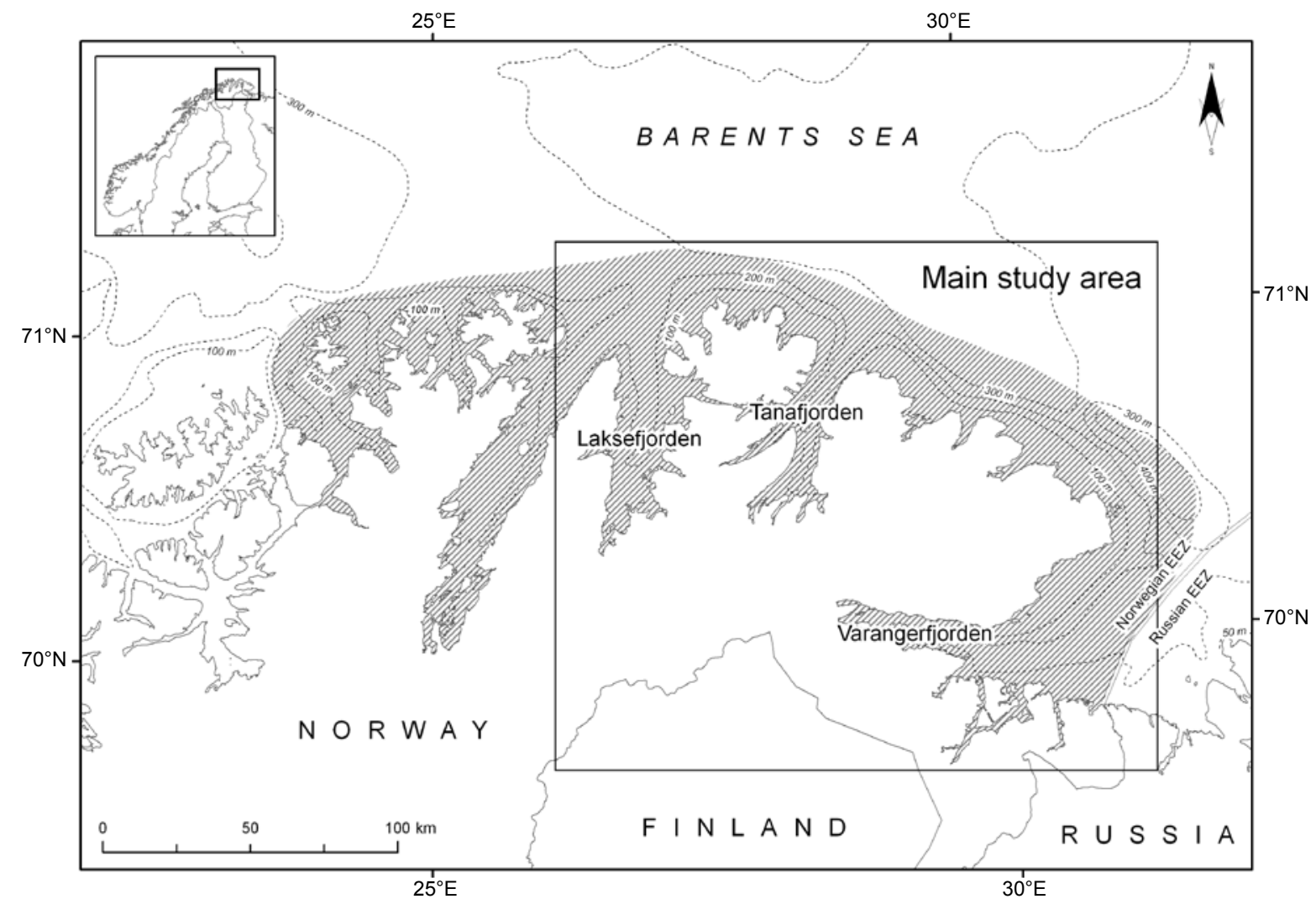

Fig. 1. Map of the County of Finnmark, with the present distribution area for red king crab in Norwegian waters and the three fjords representing the main sampling area in this study.

wide opening to the outer oceanic areas to the east, while Tanafjorden and Laksefjorden open up to the north. The water masses of these large fjords are all significantly influenced by the Norwegian Coastal Current (Sætre, 2007).

Crabs were sampled annually during autumn cruises conducted from 1994 to 2007 (Table 1). The red king crab has spread westwards along the coast, so the sampling therefore started in Varangerfjorden in 1994, in Tanafjorden in 1999 and in Laksefjorden in 2002. The sample sizes of female crab varied from 151 (Laksefjorden in 2005) to 1856 (Varangerfjorden in 2001) (Table 2). Crabs were caught by means of baited traps and a beam trawl at depths ranging from 25 to $400 \mathrm{~m}$. Both traps and trawl were used to cover a variety of bottom types. During the period 1994-2007 two types of traps have been used, conical pots and square traps. Trap construction is described by Stiansen et al. (2008) and Sundet and Hjelset (2002). Stiansen et al. (2008) have shown that the size of females caught is unrelated to pot type. An enlarged copy of a standard Agassiz trawl has
TABLE 1. Sampling period for red king crab in different years and areas in Norwegian waters.

\begin{tabular}{lccc}
\hline & \multicolumn{3}{c}{ Sample period } \\
\cline { 2 - 4 } Year & Varangerfjorden & Tanafjorden & Laksefjorden \\
\hline 1994 & $2 / 11-9 / 11$ & - & - \\
1995 & $19 / 9-28 / 9$ & - & - \\
1996 & $17 / 9-25 / 9$ & - & - \\
1997 & $16 / 9-24 / 9$ & - & - \\
1998 & $6 / 10-14 / 10$ & - & - \\
1999 & $20-24 / 10$ & $25-27 / 10$ & - \\
2000 & $9 / 8-13 / 8$ & $14 / 8-16 / 8$ & - \\
2001 & $21 / 8-29 / 8$ & $3 / 9-5 / 9$ & - \\
2002 & $14 / 8-21 / 8$ & $3 / 9-6 / 9$ & $7 / 9-8 / 9$ \\
2003 & $10 / 9-17 / 9$ & $25 / 9-27 / 9$ & $19 / 8-21 / 8$ \\
2004 & $18 / 8-28 / 8$ & $28 / 8-30 / 8$ & $31 / 8-2 / 9$ \\
2005 & $23 / 8-31 / 8$ & $31 / 8-2 / 9$ & $3 / 9-7 / 9$ \\
2006 & $22 / 8-29 / 8$ & $30 / 8-1 / 9$ & $3 / 9-5 / 9$ \\
2007 & $21 / 8-29 / 8$ & $30 / 8-1 / 9$ & $1 / 9-4 / 9$ \\
\hline
\end{tabular}




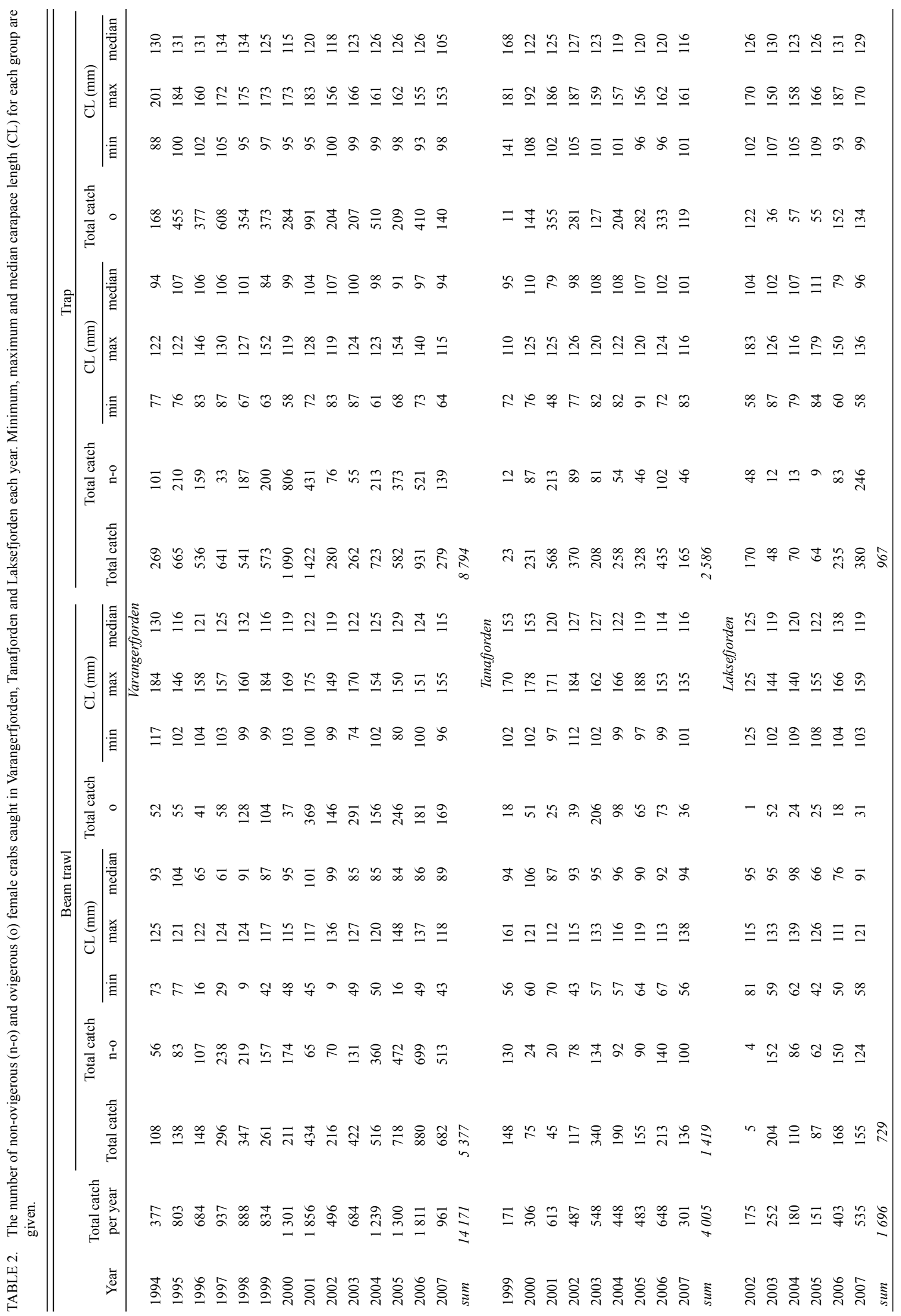


been used to collect red king crab in Norwegian waters. It has a $6 \mathrm{~m}$ wide and $1 \mathrm{~m}$ high steel frame with a net attached behind. Each side of the frame is equipped with $20 \mathrm{~cm}$ wide steel runners, and floats are attached to the top of the frame to prevent the frame from sinking into soft mud. The net is $15 \mathrm{~m}$ long from the opening to the cod end, and the mesh size is $135 \mathrm{~mm}$ in the main net and in the cod end the inner net has a mesh size of $20 \mathrm{~mm}$. The net is also equipped with floats to prevent tearing.

The red king crab fishery started as a minor research fishery with four vessels in 1994 (Table 3). The number of vessels participating has increased and in 2002 the first licences for commercial fishing of red king crab were issued. Since only small vessels $(<21 \mathrm{~m})$ are licensed, they can only operate traps. Throughout the period of exploitation the quota and effort have increased (Table 3).

During the annual scientific cruises all crabs caught were counted and measured. For each individual, carapace length and other morphological measurements were recorded to the nearest millimetre using a vernier calliper. In addition, sex and the presence of eggs were recorded for each crab. In this study, only female red king crabs that had all the various parameters measured were included in the analysis.

Catch per unit of effort (CPUE) was obtained from the annual scientific trawl cruises in the period 1995-2007. The CPUE was estimated as number of all crabs captured per hour trawling (Table 4), and represent a unit of measure of population density during the study period. In order to examine if population density has affected female size at maturity, a linear regression between estimated $50 \%$ ovigerous length $\left(O L_{50}\right)$ and CPUE values was analysed.

Females were classified as either mature or immature based on the presence or absence of eggs, which indicates whether or not successful mating and spawning has occurred. No further analysis was conducted on the barren females according to the setae stage. These observations are used to estimate the carapace length at which a randomly selected female has a $50 \%$ chance to be ovigerous (carrying eggs), also noted as $O L_{50}$. The percentage of ovigerous females, in one-millimetre carapace length classes, was calculated according to gear and fjord as well as a mean value for each fjord over the

TABLE 3. The number of vessels, fishing effort in traps allowed per boat, TAC (number) and size of the vessels participating in the research- and commercial fishery of red king crab in Norwegian waters from 1994 to 2007.

\begin{tabular}{cccccc}
\hline \hline Year & $\begin{array}{c}\text { Number } \\
\text { of vessels }\end{array}$ & $\begin{array}{c}\text { Fishing effort } \\
\text { Traps per boat }\end{array}$ & $\begin{array}{c}\text { TAC } \\
\text { (legal males) }\end{array}$ & $\begin{array}{c}\text { Harvest rate } \\
(\%)\end{array}$ & $\begin{array}{c}\text { Overall vessel } \\
\text { length }(\mathrm{m})\end{array}$ \\
\hline 1994 & 4 & 20 & $\begin{array}{c}\text { Research fishery } \\
11000\end{array}$ & 41 & $7-15$ \\
1995 & 4 & 20 & 11000 & 11 & $7-15$ \\
1996 & 6 & 20 & 15000 & 17 & $7-15$ \\
1997 & 6 & 20 & 15000 & 14 & $7-15$ \\
1998 & 15 & 20 & 25000 & 17 & $7-15$ \\
1999 & 24 & 20 & 38000 & $*$ & $7-15$ \\
2000 & 33 & 20 & 38000 & 6 & $7-15$ \\
2001 & 116 & 20 & 100000 & 22 & $7-15$ \\
2002 & 127 & 30 & 100000 & 13 & $7-15$ \\
2003 & 197 & 30 & 200000 & 15 & $7-15$ \\
2004 & 260 & 30 & 280000 & 21 & $6-21$ \\
2005 & 273 & 30 & 280000 & 34 & $6-21$ \\
2006 & 264 & 30 & 300000 & 29 & $6-21$ \\
2007 & 253 & 30 & 300000 & 31 & $6-21$ \\
\hline$*$ not available & & & &
\end{tabular}


TABLE 4. Average catch per unit of effort (CPUE) (number of crabs per trawl hour) with CI (confidence interval) of red king crab from the scientific cruises in the period 1995-2007.

\begin{tabular}{|c|c|c|c|}
\hline Year & $\begin{array}{c}\text { Varangerfjorden } \\
\text { CPUE } \pm \mathrm{CI}\end{array}$ & $\begin{array}{l}\text { Tanafjorden } \\
\text { CPUE } \pm \mathrm{CI}\end{array}$ & $\begin{array}{c}\text { Laksefjorden } \\
\text { CPUE } \pm \text { CI }\end{array}$ \\
\hline 1994 & $*$ & & \\
\hline 1995 & $10.5 \pm 3.6$ & & \\
\hline 1996 & $19.1 \pm 7.0$ & & \\
\hline 1997 & $21.0 \pm 7.7$ & & \\
\hline 1998 & $13.7 \pm 2.9$ & & \\
\hline 1999 & $17.4 \pm 4.5$ & $18.3 \pm 9.7$ & \\
\hline 2000 & $25.0 \pm 13.3$ & $5.2 \pm 2.7$ & \\
\hline 2001 & $20.5 \pm 10.0$ & $6.0 \pm 2.8$ & \\
\hline 2002 & $15.6 \pm 5.8$ & $18.9 \pm 9.7$ & $2.5 \pm 4.9$ \\
\hline 2003 & $19.7 \pm 7.5$ & $38.8 \pm 18.9$ & $37.9 \pm 71.7$ \\
\hline 2004 & $30.4 \pm 17.2$ & $25.8 \pm 8.2$ & $25.4 \pm 39.1$ \\
\hline 2005 & $33.3 \pm 21.9$ & $23.5 \pm 9.6$ & $13.0 \pm 16.0$ \\
\hline 2006 & $41.5 \pm 25.4$ & $31.0 \pm 14.2$ & $25.0 \pm 31.0$ \\
\hline 2007 & $45.8 \pm 25.7$ & $24.8 \pm 9.2$ & $25.9 \pm 19.1$ \\
\hline
\end{tabular}

entire sampling period. The $O L_{50}$ length was estimated by fitting the proportion of ovigerous females to the following logistic curve:

$$
\text { Proportion ovigerous }=\frac{1}{1+\exp \left(\alpha C L-\alpha O L_{50}\right)}
$$

where $\alpha$ is a constant and $O L_{50}$ is the length at which $50 \%$ of female crabs are ovigerous.

In order to minimize the variance of the $O L_{50}$ estimates, $O L_{50}$ estimates obtained from beam trawl and trap data were combined. A general method to combine two estimates is

$$
O L_{50}=a O L_{50 \text { trawl }}+(1-a) O L_{50 \text { trap }}
$$

Where the $a$ is calculated by

$$
a=\frac{\operatorname{Var} O L_{50 \text { trap }}}{\operatorname{Var} O L_{50 \text { trawl }}+\operatorname{Var} O L_{50 \text { trap }}}
$$

This particular choice of $a$ will minimize the variance (Var) of the combined $O L_{50}$ estimate. However the weight of $a$ could have been set at $a=1 / 2$ in order to average the two estimates. $O L_{50}$ estimates are presented with a $95 \%$ confidence interval (CI).

$O L_{50}$ values were considered statistically different when 95\% CI's did not overlap. All statistical analyses and graphical presentations were conducted using SYSTAT ${ }^{\circledR}$ (SYSTAT Software Inc.).

\section{Results}

A total of 19872 females from the three fjords were analysed for size at sexual maturity based on the presence of eggs (Table 2). The 14171 female red king crabs collected in Varangerfjorden ranged from 9 to $201 \mathrm{~mm}$ $\mathrm{CL}$, and $52 \%$ were found to be ovigerous. In Tanafjorden 4005 females ranged from 43 to $192 \mathrm{~mm} \mathrm{CL}$, and $62 \%$ of the females were carrying roe. In Laksefjorden the number of females was 1696 , with $42 \%$ being ovigerous and measured from 42 to $187 \mathrm{~mm} \mathrm{CL}$. The smallest egg-carrying female measured $93 \mathrm{~mm}$, and was caught in Laksefjorden in 2006.

Female crab CL distributions from beam trawl and trap are presented in Fig 2. The Figure illustrates that the trawl catches smaller individuals compared with the trap, and the trap catches a higher percentage of mature individuals. CL distributions of pooled female crab (with and without roe) are presented for each fjord and year in Fig. 3 and prominent modes can be identified as peaks in the length distribution, representing strong year-classes. For example, in Fig. 3A a mode at CL of approximately $100 \mathrm{~mm}$ in year 2000 can be traced in the years preceding 2006. The CL distribution also shows a large size range among mature females in all areas.

Throughout the whole period and in all areas examined, only $1.1 \%$ of the non-ovigerous females were 

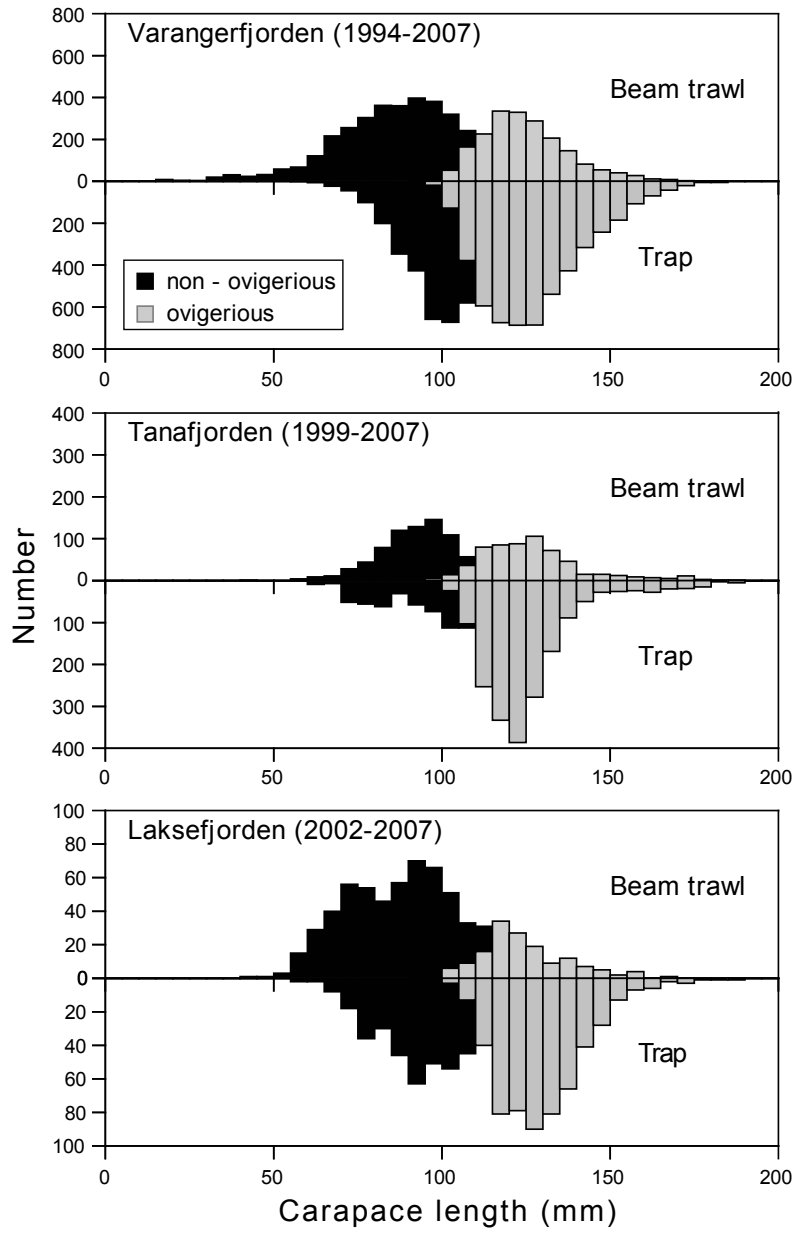

Fig. 2. Female red king crab size structure from beam trawl and trap caught in the three fjords in the sampling periods for Varangerfjorden, Tanafjorden and Laksefjorden.

larger than $120 \mathrm{~mm} \mathrm{CL}$, a size chosen where about 100\% of the females are expected to be ovigerous.

The estimated mean $O L_{50}( \pm 95 \% \mathrm{CI})$ for all years combined was $108.9 \pm 0.2 \mathrm{~mm}, 108.7 \pm 0.3 \mathrm{~mm}$ and $111.8 \pm 0.5 \mathrm{~mm}$ for Varangerfjorden, Tanafjorden and Laksefjorden, respectively. No significant difference between Varangerfjorden and Tanafjorden was found regarding $O L_{50}$ (Fig. 4). Laksefjorden had a statistically significant larger $O L_{50}$ value compared to the other two fjords, although the difference was minor. Changes in $O L_{50}$ value before and after the onset of a commercial fishery was analysed for Varangerfjorden. Estimated $O L_{50}$ for the research fishing period (1994-2001) was $108.9 \pm 0.2 \mathrm{~mm}$ and for the commercial fishing period (2002-2007) $108.8 \pm 0.2 \mathrm{~mm}$.

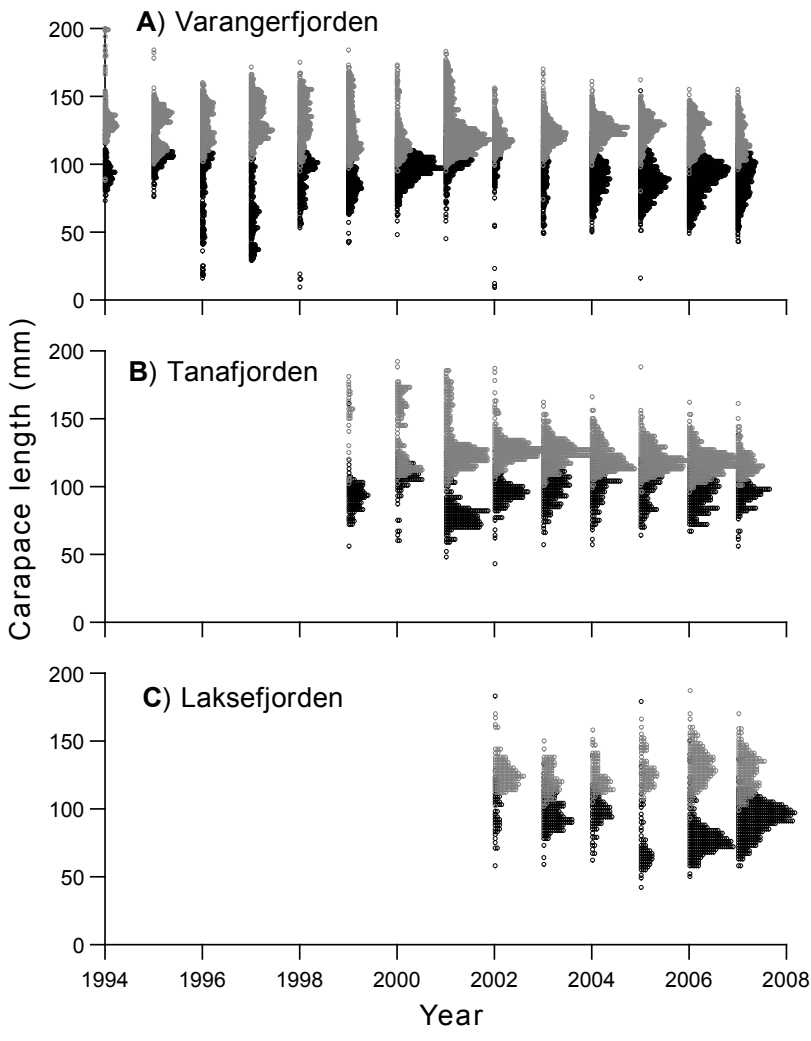

Fig. 3. Female red king crab carapace length distribution from autumn cruises conducted between 1994 and 2007 in the three fjords of (A) Varangerfjorden, (B) Tanafjorden and (C) Laksefjorden. Non-ovigerous females (black) and ovigerous female (grey).

There was no statistically significant linear relationship between estimated $O L_{50}$ values and CPUE for each year in the three fjords studied. A scatterplot of the data is presented for Varangerfjorden in Fig. 5, which has the longest time series.

\section{Discussion}

Red king crab inhabit water masses at depths of 20 to $300 \mathrm{~m}$ (Wallace et al., 1949; Powell and Nickerson, 1965), and their spatial distribution is dependent on sex, size and maturity stage. To cover different bottom habitats and depth ranges in the fjords, crabs were collected using both traps and beam trawl. Different sampling gear may give different compositions of size and sex (Smith et al., 2004). It has been shown that trawls collect a wider range of crab sizes (Smith et al., 2004) and that immature crabs actively avoid traps when mature individuals are in the trap (Jivoff and Hines, 1998). Traps provide the advantage of catching crabs in areas unfavourable for 


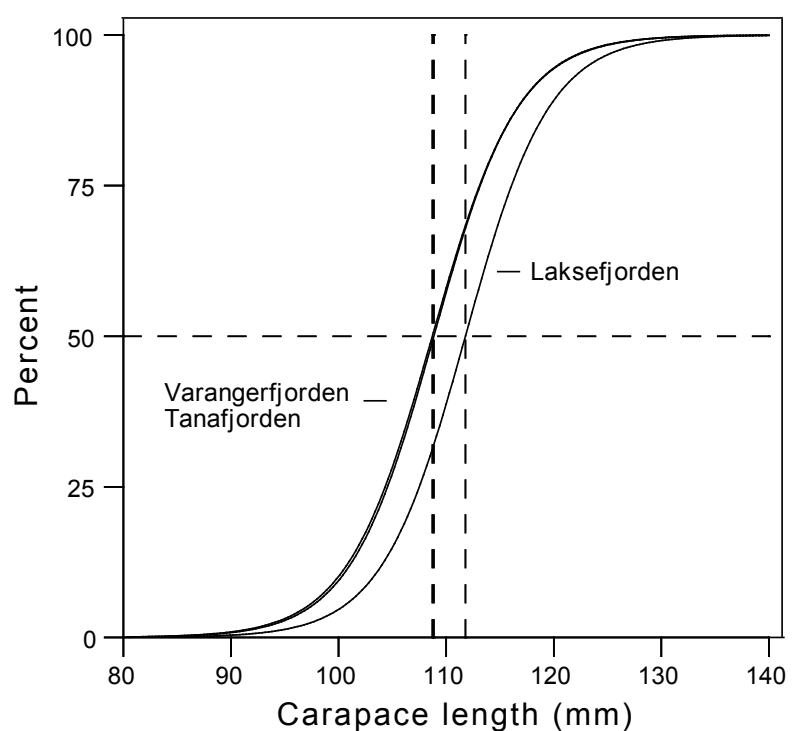

Fig. 4. Female red king crab estimated ovigerous length $\left(O L_{50}\right)$ from Varangerfjorden, Tanafjorden and Laksefjorden, based on logistic model fitted using females from 70 to $150 \mathrm{~mm} \mathrm{CL}$.

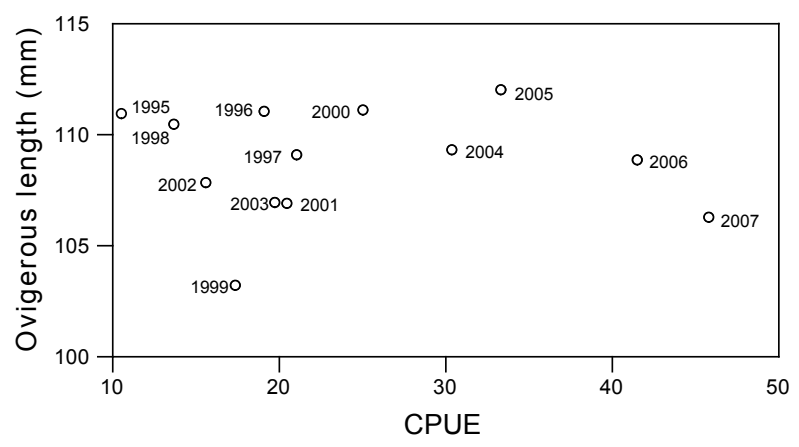

Fig. 5. Ovigerous length $\left(O L_{50}\right)$ versus calculated CPUE values from Varangerfjorden from 1995 to 2007. The data points are labeled with corresponding year.

trawling. In the present study, combined data from both sampling methods were used in the analysis. Otto et al. (1990) recommend pooling data from different sampling methods when estimating size at maturity in crabs to reduce bias in the results.

In the present study we have used the presence of eggs to determine sexual maturity in red king crab females. This is an effective method, which simply involves inspection of the crab's abdomen, and a large sample size can be achieved with relatively small effort. The presence of eggs is conclusive evidence of sexual maturity, and is also the most commonly used method in crab maturity studies (Somerton, 1981) that facilitates comparison of populations.
The female red king crab size distribution in our study shows fluctuations in the relative abundance of mature and immature females between years and geographic areas (Varangerfjorden, Tanafjorden and Laksefjorden). Year-classes can be identified as prominent modes. Females show a gradual decline in growth increment when they mature (Nilssen and Sundet, 2006) and exhibit further decreases during subsequent moults (Stevens and Swiney, 2007b). This study showed that in captive crabs, pubertal females (with mature ovaries, just prior to moult to maturity) have an increment of $16.2 \mathrm{~mm}$. Primiparous females (carrying their first clutch of eggs) have an increment of $7.5 \mathrm{~mm}$ and multiparous females (carrying second or later clutch of eggs) have an increment of $4.7 \mathrm{~mm}$. This reduction in increment makes the identification of year-classes from the size distribution difficult with increasing size in ovigerous females. In each fjord, ovigerous females showed a large size range, indicating that they continue to reproduce throughout life. We believe that the temporal fluctuations in $O L_{50}$ are mainly caused by differences in year-class strength. This is consistent with Otto et al. (1990) which recommended pooling of data to even out the year-to-year variation.

Varangerfjorden was subject to the longest sampling timeframe and fishing pressure. We therefore examined the variation in $O L_{50}$ and the two different fishing regimes in this fjord. There was no difference in the estimated $O L_{50}$ value between the two fishing regime periods, so the transition from a research fishery to a commercial fishery seemed to have no impact on the $O L_{50}$ value. The alteration in crab density over years had no effect on the $O L_{50}$ values either.

Our results show larger year-to-year variations compared to those from Bristol Bay, Alaska (Otto et al., 1990). Otto et al. (1990) suggested size at maturity is less stable in small populations compared to large populations, and, in this context, we consider the population in the Norwegian waters to be small. We pooled data for the period 1994-2007 for the three fjords to facilitate comparison with other studies, and to avoid bias in estimates.

The mean $O L_{50}$ values calculated from pooled data for each fjord did not vary significantly between areas, and that the mean $O L_{50}$ values are greater compared to those derived from native areas in the North Pacific Ocean. Female red king crab in the eastern Bering Sea become mature at a carapace length of $102 \mathrm{~mm}$ (data from Wallace et al., 1949, recalculated by Somerton, 1980), a carapace length of 89 mm in Adak (Blau, 1990), 
a carapace length of $71 \mathrm{~mm}$ in Norton Sound, a carapace length of $89 \mathrm{~mm}$ in Bristol Bay and carapace length of $102 \mathrm{~mm}$ in Pribilof area (Otto et al., 1990). Earlier studies do not report size at maturity as a single value, but as a range, as exemplified by Weber (1967), who reported maturity to span 90-100 mm CL for females in the south-eastern Bering Sea. Wallace et al. (1949) reported a range of 86-102 $\mathrm{mm} \mathrm{CL}$ in the eastern Bering Sea and corresponding values of 93-112 mm for the Pacific Ocean. Otto et al. (1990) concluded that the observed variations in size at maturity within the region could be a result of latitude, temperature, available food resources and growth rate.

Altered size at sexual maturity in a population can be caused by different factors. The $O L_{50}$ value used here is a function of the relative proportion of mature and immature crabs in the stock. Large females in the maturation size range which fail to reproduce, for instance, due to a lack of large males, would be incorrectly categorised as immature, resulting in an underestimation of the number of mature females and, correspondingly, an increase in the $O L_{50}$ estimate. In our study this is considered a minor problem, since large barren females constituted only $1.1 \%$ of the total number of non-ovigerous females. A high mortality rate among newly mature crabs would give the same result. $O L_{50}$ is also affected by variation in year-class strength; an abundant year-class entering the maturing size range will reduce the percentage of mature crabs, giving an increase in the $O L_{50}$ value (Somerton, 1981). We have no reason to believe that unsuccessful spawning and high mortality among newly mature females are important in our crab population. Varying year-class strength though, may explain the large size at maturity in the rapidly growing red king crab stock in Norwegian waters, as indicated by a stable $O L_{50}$ during a period of increasing stock index in all the fjords examined.

The red king crab stock in Norwegian waters has grown in the course of the last 30 years. The overall harvest rate was low until 2001, after which it increased along with the growth of the stock. It has been shown that fisheries can affect life history traits in both finfish and crustaceans (Pollock et al., 1995; Jørgensen et al., 2007). These evolutionary changes may occur after extended periods of heavy fishing pressure; hence the fishery in our study is likely to have little or no effect on this parameter.

Fourteen years (1994-2007) of red king crab survey data from Norwegian waters reveal that the female red king crab matures at larger sizes compared to those found in native areas. There are both temporal and spatial fluctuations in size at sexual maturity in the current study, which probably reflect the composition of year-classes in the mature part of the female stock. As noted by Otto et al. (1990), monitoring of this parameter should be based on data from several areas and years. It is of importance that data are collected on an annual basis throughout the range of the population and that a mean $O L_{50}$ value is presented in time intervals of, for example, five to ten years to reveal any significant change. Fishing pressure directed at large males seems not to have affected the size at sexual maturity in the female red king crab. Small variations in $O L_{50}$ values indicate higher levels of precision on the estimates and support the method used in this study, and this should continue to be used in monitoring and appropriate management. Fecundity and recruitment in this population must also be analysed in order to gain a broader knowledge of the population's reproductive potential, which in turn will form the basis for adequate management regimes.

\section{Acknowledgement}

We are grateful for the assistance and enthusiastic support during the cruises from the skipper and the crew on RV “Johan Ruud". Thanks go to colleague Dr. T. A. Øigård who helped with statistical formulas when combining data from traps and trawls. We also thank anonymous referees for valuable comments which have improved the manuscript.

\section{References}

BLAU, S. F. 1990. Size at maturity of female red king crabs (Paralithodes camtschatica) in the Adak Management Area, Alaska. In: Proceedings of the International Symposium on King and Tanner Crabs. B. Metleff (ed.). Alaska Sea Grant College Program Report, 90-04: 105-116.

DONALDSON, W. E., and W. K. DONALDSON. 1992. A review of the history and justification for size limits in Alaskan king, tanner, and snow crab fisheries. Fish. Res. Bull., 92-02, 22 p.

HAYES, M. L., and D. T. MONTGOMERY. 1963. Movement of king crabs tagged and released in Shumagin Island Area, 1957-1962. U.S Fish and Wildlife Service. Special Scientific Report, Fisheries, 458, 7 p.

JIVOFF, P., and A. H. HINES. 1998. Female behaviour, sexual competition and mate guarding in the blue crab, Callinectes sapidus. Anim. Behav., 55: 589-603. doi:10.1006/ anbe. 1997.0646

JØRGENSEN, C., K. ENBERG, E. S. DUNLOP, R. ARLINGHAUS, D. S. BOUKAL, K. BRANDER, B. ERNANDE, A. GARDMARK, F. JOHNSTON, S. MATSUMURA, H. PARDOE, K. RAAB, A. SILVA, A. VAINIKKA, U. DIECKMANN, M. HEINO, and A. D. RIJNSDORP. 
2007. Ecology-managing evolving fish stocks. Science, 318: $1247-1248$. doi: $10.1126 /$ science. 1148089

KRUSE, G. H. 1993. Biological perspectives on crab management in Alaska. In: Proceedings of the international symposium on management strategies for exploited fish populations. G. H. Kruse, D. M. Eggers, R. J. Marasco, C. Pautzke and T. J. Quinn II (eds.). University of Alaska Sea Grant College Program Report 93-02: 355-384.

KUZMIN, S. A., S. OLSEN, and O. GERASIMOVA. 1996. Barents Sea King Crab (Paralithodes camtschaticus): Transplantation experiments were successful. In: High latitude crabs: biology, management, and economics. Alaska Sea Grant College Program Report No. 96-02, University of Alaska Fairbanks: 649-663.

MARUKAWA, H. 1933. Biological and fishery research on Japanese king crab Paralithodes camtschatica (Tilesius). J. Imp. Fish. Exp. Sta., 4: 123-152.

MCCAUGHRAN, D. A., and G. C. POWELL. 1977. Growthmodel for Alaska king crab (Paralithodes camtschatica). J. Fish. Res. Board Can., 34: 989-995.

NILSSEN, E. M., and J. H. SUNDET. 2006. The introduced species red king crab (Paralithodes camtschaticus) in the Barents Sea: II. Growth increments and moulting probability. Fish. Res., 82: 319-326. doi:10.1016/j.fishres.2006.05.008

ORLOV, Y. I., and B. G. IVANOV. 1978. Introduction of Kamchatka king crab Paralithodes camtschatica (Decapoda Anomura Lithodidae) into Barents Sea. Mar. Biol., 48: 373-375. doi:10.1007/BF00391642

ORLOV, Y. I., and A. F. KARPEVICH. 1965. On the introduction of the commercial crab Paralithodes camtschatica (Tilesius) into the Barents Sea. In: ICES Special Meeting in 1962 to consider problems in the exploitation and regulation of fisheries for Crustacea. H. A. Cole (ed.). Rapp. P.-v. Réun. Cons. int. Explor. Mer., 156: 59-61.

OTTO, R. S. 1986. Management and assessment of eastern Bering Sea king crab stocks. In: North Pacific Workshop on stock assessment and management of invertebrates. G.S. Jamieson, N Bourne (ed.). Can. Spec. Publ. Fish Aquat. Sci., 92: 83-106.

OTTO, R. S., R. A. MACINTOSH, and P. A. CUMMISKEY. 1990. Fecundity and other reproductive parameters of female red king crab (Paralithodes camtschatica) in Bristol Bay and Norton Sound, Alaska. In: Proceedings of the International Symposium on King and Tanner Crabs. B. Metleff (ed.). Alaska Sea Grant College Program Report, 90-04: 65-90.

POLLOCK, D. E. 1995. Changes in maturation ages and sizes in crustacean and fish populations. S. Afr. J. Mar. Sci., 15: 99-103.

POWELL, G. C., and R. B. NICKERSON. 1965. Reproduction of king crabs, Paralithodes camtschatica (Tilesius). J. Fish. Res. Board Can., 22: 101-111.

SMITH, K. D., N. G. HALL, S. DE LESTANG, and I. C.
POTTER. 2004. Potential bias in estimates of the size of maturity of crabs derived from trap samples. ICES J. Mar Sci., 61: 906-912. doi:10.1016/j.icesjms.2004.07.019

SOMERTON, D. A. 1980. A computer technique for estimating the size of sexual maturity in crabs. Can. J. Fish. Aquat. Sci., 37: 1488-1494.

1981. Regional variation in the size of maturity of 2 species of tanner crab (Chionoecetes bairdi and Chionoecetes opilio) in the Eastern Bering Sea, and its use in defining management subareas. Can. J. Fish. Aquat. Sci., 38: $163-174$. doi:10.1139/f81-022

STEARNS, S. C. 1976. Life-history tactics - review of ideas. Q. Rev. Biol., 51: 3-47. doi:10.1086/409052

1992. The evolution of life histories. University Press, Oxford. 262 p.

STEVENS, B. G., and K. M. SWINEY. 2007a. Hatch timing, incubation period, and reproductive cycle for captive primiparous and multiparous red king crab, Paralithodes camtschaticus. J. Crustacean Biol., 27: 37-48. doi:10.1651/S-2663.1

2007b. Growth of female red king crabs Paralithodes camtschaticus from Kodiak, Alaska, during pubertal, primiparous, and multiparous molts. Alaska Fish. Res. Bull., 12: 270-277.

STIANSEN, S., A. FERNÖ, D. FUREVIK, T. JØRGENSEN, and S. LØKKEBORG. 2008. Efficiency and catch dynamics of collapsible square and conical crab pots used in the red king crab (Paralithodes camtschaticus) fishery. Fish. Bull., 106: 40-46.

SUNDET, J. H., and A. M. HJELSET. 2002. The Norwegian red king crab (Paralithodes camtschaticus) fishery: management and bycatch issues. In: Crabs in cold water regions: biology, management, and economics. A.J Paul, E.G. Dawe, R. Elner, G.S. Jamieson, G.H. Kruse, R.S Otto, B. Sainte-Marie, T.C Shirley, D. Woodby (eds.). University of Alaska Sea Grant College Program, AKSG-02-01: 681-692.

SÆTRE, R. 2007. Studies of the coastal region. Background and history. In: The Norwegian coastal current - oceanography and climate. R. Sætre (ed.). Tapir Academic Press. p. 19-34.

TRIPPEL, E.A. 1995. Age at maturity as a stress indicator in fisheries. BioScience, 45: 759-771. doi:10.2307/1312628

WALLACE, M. M., C. J. PERTUIT, and A. R. HVATUM. 1949. Contribution to the biology of the king crab (Paralithodes camtschatica Tilesius). U.S. Fish Wildl. Serv., Fish. Leafl., 340, 50 p.

WATTERS, G., and A. J. HOBDAY. 1998. A new method for estimating the morphometric size at maturity of crabs. Can. J. Fish. Aquat. Sci., 55: 704-714. doi:10.1139/cjfas-55-3-704

WEBER, D. D. 1967. Growth of the immature king crab, Paralithodes camtschatica (Tilesius). Int. North Pac. Fish. Comm., Bull., 21: 21-53. 